\title{
Do they really hybridize? A field study in artificially established mixed populations of Euphrasia minima and E. salisburgensis (Orobanchaceae) in the Swiss Alps
}

\author{
Burgi Liebst
}

Received: 20 June 2006/Accepted: 21 December 2007/Published online: 15 May 2008

(C) Springer-Verlag 2008

\begin{abstract}
Hybridization and introgression in the European species of Euphrasia depend on the relationships between the species, on flower size and habitat. Hybridization between Euphrasia minima and Euphrasia salisburgensis was investigated in their natural habitat using artificial sympatric populations of both species in the Swiss Alps. The insect behavior in the populations suggests, that cross-pollination is likely to occur. A number of putative hybrids were detected by morphological characteristics, and their hybrid origin was verified using RAPD analysis. The predominance of RAPD bands in one of the species and the occurrence of these bands in some plants of the second species point to earlier introgression events. The number of hybrids found in the artificial populations together with results of earlier studies indicate that insect visits and cross-pollination in small-flowered Euphrasia species in lower alpine regions may be more common than has been suggested in the past.
\end{abstract}

\section{Keywords Euphrasia minima .}

Euphrasia salisburgensis . Field experiment .

Insect behavior - Hybridization · Introgression .

RAPD · Discriminant analyses

\section{Introduction}

The Euphrasia species of the Northern Hemisphere (section Euphrasia) are hemiparasitic herbs of either subsection Ciliatae or subsection Angustifoliae. Within both

B. Liebst $(\bowtie)$

Institut für systematische Botanik, Universität Zürich,

Zollikerstr. 107, 8008 Zürich, Switzerland

e-mail: burgi.liebst@systbot.uzh.ch subsections taxonomy is difficult due to large intraspecific variability, to small interspecific differences and to the occurrence of hybrids (Yeo 1968). The close relatedness of some of the species within the same subsection is reflected by successful interspecific cross-pollination (Liebst and Schneller 2005; Yeo 1966, 1976). Artificial crosses of taxa of different subsections may result either in low seed set or in a seed set similar to that resulting from intraspecific crossing or selfing. The $\mathrm{F} 1$ hybrids of such crosses are either sterile or bear only a few seeds (Liebst 2006; Yeo 1966). In a few cases, hybridization between diploid and tetraploid Euphrasia species has been observed (Liebst and Schneller 2005; Pugsley 1930; Yeo 1956).

Artificial pollination may illustrate the interfertility of species, but cannot be used to estimate the probability or the frequency of interspecific cross-pollination in nature. Preconditions for hybridization between insect-pollinated species include the occurrence of at least two species in the immediate neighborhood and of overlapping flowering periods. Mixed populations of Euphrasia species have frequently been found in Europe (von Wettstein 1893; Yeo 1966). The probability of interspecific cross-pollination in these populations depends on the availability of pollinators and on the breeding system of the taxa, which is strongly associated with the size of the corolla (von Wettstein 1896; Yeo 1966, 1978a; French et al. 2005). Cross-pollination is common in large-flowered species, whereas the small-flowered species are predominantly selfing. In alpine populations of the small-flowered E. minima and E. willkommii few or no flower visitors have been detected (Kreisch 1996; Gomez 2002). However, a few hybrids of small flowered alpine Euphrasia taxa have been found in the last two centuries suggesting that cross-pollination at least occasionally occurs (see references in von Wettstein 1896; Vitek 1986). 
Both the small and the large flowers of Euphrasia are adapted to the same type of pollinators (Yeo 1968) and are mainly visited and pollinated by flies, hover flies (Diptera, Syrphidae) and bees (Hymenoptera, Apidae s.1.). According to Schultz (see Knuth 1909) the nectary is well developed in the larger-flowered species and less well developed or absent in the smaller-flowered ones. Pollen seems to be at least as much an attraction as the nectar, particularly for Syrphidae (Yeo 1968). The mechanisms of pollination in Euphrasia and the flower biology have been described in detail by von Wettstein (1896) and Yeo (1968).

The tetraploid, small-flowered species E. minima (subsection Ciliatae) and E. salisburgensis (subsection Angustifoliae) are among the most common Euphrasia species in the Swiss Alps. Despite their different ecological preferences, sympatric and parapatric populations occur. Both species are successfully selfing (Liebst 2006). It is unlikely that their flowers may attract many insects, however, Yeo (1966) argued that even between small-flowered Euphrasia species crosses may be common. Because $E$. minima and E. salisburgensis belong to different subsections, it is expected that hybrids are highly sterile (Yeo 1968). Nevertheless, an artificial F2 generation was raised in a garden experiment from seed resulting from artificial selfing and crossing of $\mathrm{F} 1$ hybrids of $E$. minima and $E$. salisburgensis, and from artificial back-crossing of the F1 hybrids with the parental species (Liebst 2006).

So far, inter- and intraspecific crossing and selfing in Euphrasia have been investigated exclusively by artificial pollination (Liebst 2006; Yeo 1976). In the present study, for the first time pollination by insects and hybridization in the natural habitat of the species were investigated. Artificially established, mixed populations of $E$. minima and $E$. salisburgensis were used to answer the following questions: (1) Do the flowering periods of E. minima and E. salisburgensis overlap sufficiently to allow interspecific pollination? (2) Are the flowers of E. minima and E. salisburgensis visited by insects and does the insect's behavior potentially allow pollen transfer between the species? (3) Can hybrids establish in a natural habitat?

\section{Materials and methods}

\section{Species}

Euphrasia minima Jacq. ex DC., subsection Ciliatae, and E. salisburgensis, subsection Angustifoliae (Wettst.) Joerg. are annual, hemiparasitic herbs. E. minima is a facultative hemiparasite but grows much more vigorously when it is attached to a suitable host plant (Heinricher 1924; Matthies 1998). Although many species are suitable hosts for
Euphrasia, there are strong differences in their quality as host plants (Yeo 1964; Matthies 1998).

Both E. minima and E. salisburgensis are widespread in the Alps. In Switzerland, the altitudinal distribution of $E$. salisburgensis ranges from colline to alpine regions, while E. minima is usually restricted to subalpine and alpine regions (Hess et al. 1972). E. salisburgensis grows mainly on basic soils, E. minima prefers acidic substrates. The species can be morphologically separated by the two main characters used for the separation of the subsections: in subsection Ciliatae ciliate capsules and leaves with contiguous teeth; in subsection Angustifoliae glabrous capsules (or capsules with few small cilia) and leaves with at least some teeth distant (Yeo 1978). The color of the corolla is yellow or white in E. minima and white or lilac in $E$. salisburgensis. Like most Euphrasia flowers they also have violet longitudinal veins forming guide marks that converge to the throat (Yeo 1966) and yellow spots on the lower lip and throat.

\section{Establishment of the artificial populations}

Two to three ripe fruits from about 400 individuals of $E$. minima and E. salisburgensis were collected at three locations in the Swiss Alps in large sympatric or parapatric populations in autumn 2001: (1) Canton Tessin, Piora (PI); Alpe Tom $\left(2,049 \mathrm{~m}, 46^{\circ} 32^{\prime} 51.69^{\prime \prime} \mathrm{N} 8^{\circ} 41^{\prime} 19.65^{\prime \prime} \mathrm{E}\right)$ to Cadagno di fuori, Cadagno di dentro and Alpe di Piora (2,013 m, 46 $\left.32^{\prime} 50.62^{\prime \prime} \mathrm{N} 8^{\circ} 42^{\prime} 56.33^{\prime \prime} \mathrm{E}\right)$; (2) Canton Uri, Andermatt (AM); Nätschen (rail stop Matterhorn-Gotthard Bahn, $\left.1,890 \mathrm{~m}, 46^{\circ} 38^{\prime} 38.66^{\prime \prime} \mathrm{N} 8^{\circ} 36^{\prime} 37.05^{\prime \prime} \mathrm{E}\right)$ to Gütsch

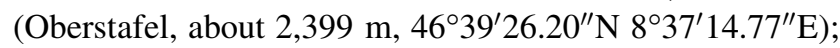
(3) Canton Tessin, Valle Bedretto (VB); Alpe Cruina $\left(2,050 \mathrm{~m}, \quad 46^{\circ} 28^{\prime} 21.17^{\prime \prime} \mathrm{N} \quad 8^{\circ} 25^{\prime} 34.93^{\prime \prime} \mathrm{E}\right)$. From here onward these populations are named "origin populations". To facilitate the discrimination of the species in the artificial populations, yellow flowered E. minima individuals were chosen as seed donors. Fruit collecting resulted in about 12,000 seeds per species and population, except for E. salisburgensis in VB, where only 7,000 seeds were collected (for details see Liebst 2006).

The experimental area was a $15 \times 7 \mathrm{~m}$ plot in a pasture in the Pian Murinascia in Val Piora (Canton TI, about $\left.1,980 \mathrm{~m}, 46^{\circ} 32^{\prime} 40.98^{\prime \prime} \mathrm{N} 8^{\circ} 43^{\prime} 46.80^{\prime \prime} \mathrm{E}\right)$. In this area single E. minima and E. salisburgensis plants and also some E. alpina (diploid, atypical forms) and E. hirtella plants (diploid) naturally occurred. Within the experimental area for each origin population four plots of $75 \times 75 \mathrm{~cm}$ (without Euphrasia plants) were prepared for seeding by cutting away grass and herbs and then removing the plant litter. For a more even distribution of the seeds, each plot was divided in nine sub plots $(25 \times 25 \mathrm{~cm})$. The seeds from each origin population were mixed. About 300 of 
each E. minima and E. salisburgensis seeds were sown into each subplot of the populations PI and AM, and about 300 E. minima and 190 E. salisburgensis seeds were sown in each subplot of the population VB. After sowing, the seeds were covered with a fine layer of quartz sand.

\section{Record of flowering plants}

The number of E. minima and E. salisburgensis plants were counted at seven days during the flowering-period in 2002 and at six days in 2003. All plants with at least one open flower were counted. Based on these data, the day with the maximum number of flowering plants (peak of flowering) and the sowing success were determined (proportion of seeds that developed into a mature plant at the peak of flowering in 2002).

\section{Observation of flower visitors}

In the vegetation periods 2002 and 2003 a total of 10210 min observation periods (between 08.00 and 18.00) were carried out in the artificial populations. During the observation periods the behavior of any insect that visited a flower of E. minima or E. salisburgensis, discriminating between Hymenoptera and Diptera and ants, butterflies or beetles, respectively, was described. Insect behavior was recorded until $10 \mathrm{~min}$ were over, until the insect visited the flower of a different genus or until the insect left the plot (whichever was shorter). The behavior of the insects as either: (1) visiting one Euphrasia flower, (2) visiting two or more flowers within the same inflorescence, (3) visiting two or more flowers of different individuals of the same Euphrasia species, (4) visiting two or more flowers of individuals of different Euphrasia species were described. For the latter E. hirtella and E. alpina that also occurred in some of the plots were included. Some beetles sitting in Euphrasia flowers were caught and determined to family level.

Additional to the 10-min observation periods any flower visitor that was present during the flowering plant counts was also recorded. A chi-square test was applied to test the dependence of insect visits on the species.

\section{Morphological analyses}

For the morphological analyses, plants in the artificial populations in 2003 and 2004 were collected. Altogether 88 Euphrasia plants from the population PI, 74 plants from the population AM, and 52 plants from VB were used for morphological and discriminant analyses.

All plants were determined according to Hess et al. (1972). If a plant showed characters both of E. minima and E. salisburgensis and/or if its corolla changed color from yellow to white, it was considered as plant of hybrid origin and is referred to as such.

The flower color of each plant was recorded and then all plants were pressed and dried. A calyx and the largest of the bracts with the maximum number of teeth were mounted on a sheet of paper using transparent adhesive tape, and photographed with a digital camera. Quantitative characters of calyces and leaves were measured using the program tpsDig 2.02 (Rohlf 2004). Quantitative flower and fruit characters were measured under a stereomicroscope at magnifications of 6.4 and $16 \times$, respectively, in one fully developed flower and in one fruit per plant after boiling. Four qualitative and 12 quantitative characters were scored and two ratios were calculated (Table 1; Fig. 1).

Data from all populations were pooled for statistical analyses. Mean and standard error were calculated for species and hybrids. Because most of the data did not show normality even after transformation, differences between

Table 1 List of characters

\begin{tabular}{|c|c|c|}
\hline \multicolumn{3}{|c|}{ Qualitative characters } \\
\hline \multirow[t]{4}{*}{ Flowers } & Color $^{\mathrm{a}}$ & 1 White \\
\hline & & 2 Yellow \\
\hline & & 3 Yellow to white \\
\hline & & 4 Violet \\
\hline \multirow[t]{2}{*}{ Bracts } & Hairs on the underside ${ }^{a}$ & 0 Absent \\
\hline & & 1 Present \\
\hline \multirow[t]{5}{*}{ Capsules } & Cilia on the retuse apex ${ }^{a}$ & 1 Absent \\
\hline & & $2<0.2 \mathrm{~mm}$ \\
\hline & & $3 \geq 0.2 \mathrm{~mm}$ \\
\hline & Cilia on the surface ${ }^{a}$ & 0 Absent \\
\hline & & 1 Present \\
\hline \multicolumn{3}{|c|}{ Quantitative characters } \\
\hline \multirow[t]{6}{*}{ Leaves } & Total length $(a)^{a}$ & $\mathrm{~mm}$ \\
\hline & Largest width between two teeth (b) & $\mathrm{mm}$ \\
\hline & Lateral length of the top tooth $(\mathrm{c})^{\mathrm{a}}$ & $\mathrm{mm}$ \\
\hline & Width of the upper lateral tooth $(\mathrm{d})^{\mathrm{a}}$ & $\mathrm{mm}$ \\
\hline & Angle of the top tooth $(\mathrm{e})^{\mathrm{a}}$ & \\
\hline & Number of leaf teeth pairs & \\
\hline Flowers & Length of the upper lip (f) & $\mathrm{mm}$ \\
\hline \multirow[t]{3}{*}{ Calyces } & Toothlength $(\mathrm{g})^{\mathrm{a}}$ & $\mathrm{mm}$ \\
\hline & Toothlengt $(\mathrm{h})^{\mathrm{a}}$ & $\mathrm{mm}$ \\
\hline & Width of the calyx (i) ${ }^{\mathrm{a}}$ & $\mathrm{mm}$ \\
\hline \multirow[t]{2}{*}{ Stems } & Number of lateral shoots ${ }^{\mathrm{a}}$ & \\
\hline & Nodium of the first flower & \\
\hline \multicolumn{3}{|l|}{ Indices } \\
\hline \multirow[t]{2}{*}{ Leaves } & Ratio total length (a)/width (b) ${ }^{\mathrm{a}}$ & \\
\hline & Ratio total length (a)/tooth length (c) $)^{a}$ & \\
\hline
\end{tabular}

Small types in parenthesis refer to Fig. 1

a Characters that were used in the discriminant analyses in at least one artificial population 
Fig. 1 Measured characters. Leaves: total length (a), largest width between two teeth (b), lateral length of the top tooth (c), width of the upper lateral tooth (d), angle of the top tooth (e). Flowers: length of the upper lip (f). Calyces: length of a tooth, margin (g) and (h), width of the calyx (i)
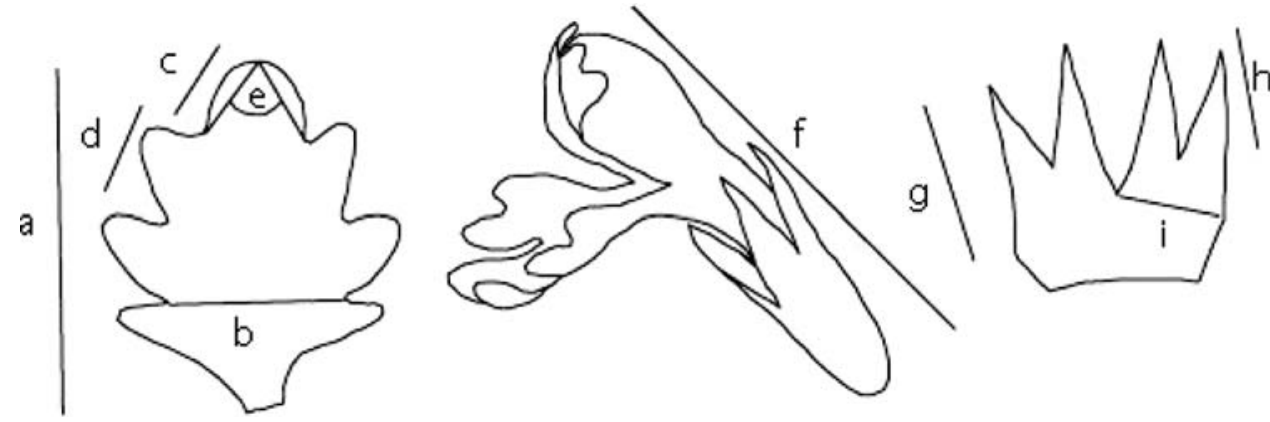

The DNA concentration was determined by visualizing the samples on $0.8 \%(\mathrm{w} / \mathrm{v})$ agarose gel electrophoresis in $1 \times$ TAE buffer and by comparing the band intensity with DNA standards. The DNA concentration of the samples varied between $<3$ and $6 \mathrm{ng} / \mu \mathrm{l}$.

Primer screening was performed using four individuals of each species and 55 of altogether 80 primers (Operon Technologies, kit A-D). Twenty-seven primers yielded in amplification products, six of them produced 40 reproducible bands. The reproducibility of the patterns was tested by repeated amplifications and by variation of the reaction mixtures (modifying the $\mathrm{MgCl}_{2}$ and/or DNA concentration). The PCR reactions were performed according to Liebst (2006).

The plants from PI, VB and AM were analyzed separately. The amplification products for the different samples were compared with each other and screened for the presence or absence of specific bands. A similarity coefficient $\mathrm{S}=M_{\mathrm{ab}} / N_{\mathrm{t}}$ was calculated for each pair of individuals (De Greef and Triest 1999) and each primer, where $M_{\mathrm{ab}}$ is for the number of all matches in the two individuals tested and $N_{\mathrm{t}}$ stands for the total number of different bands identified for the tested primer (being constant for each primer). The resulting similarity matrix was the basis for a cluster analysis (UPGMA clustering, Ntsyspc2.02i, Exeter software, 1986-1998).

\section{Results}

Sowing success and flowering phenology

The sowing success varied between about 3.3 and $4.2 \%$ in E. minima and between about 4.4 and $5.0 \%$ in E. salisburgensis. The flowering period of both species overlapped in all populations (Fig. 2).

Flower visitors

In 30 of the overall 102 observation periods $(17 \mathrm{~h})$ at least one insect visited one or more flowers of E. minima or E. salisburgensis. During the counting of flowering 

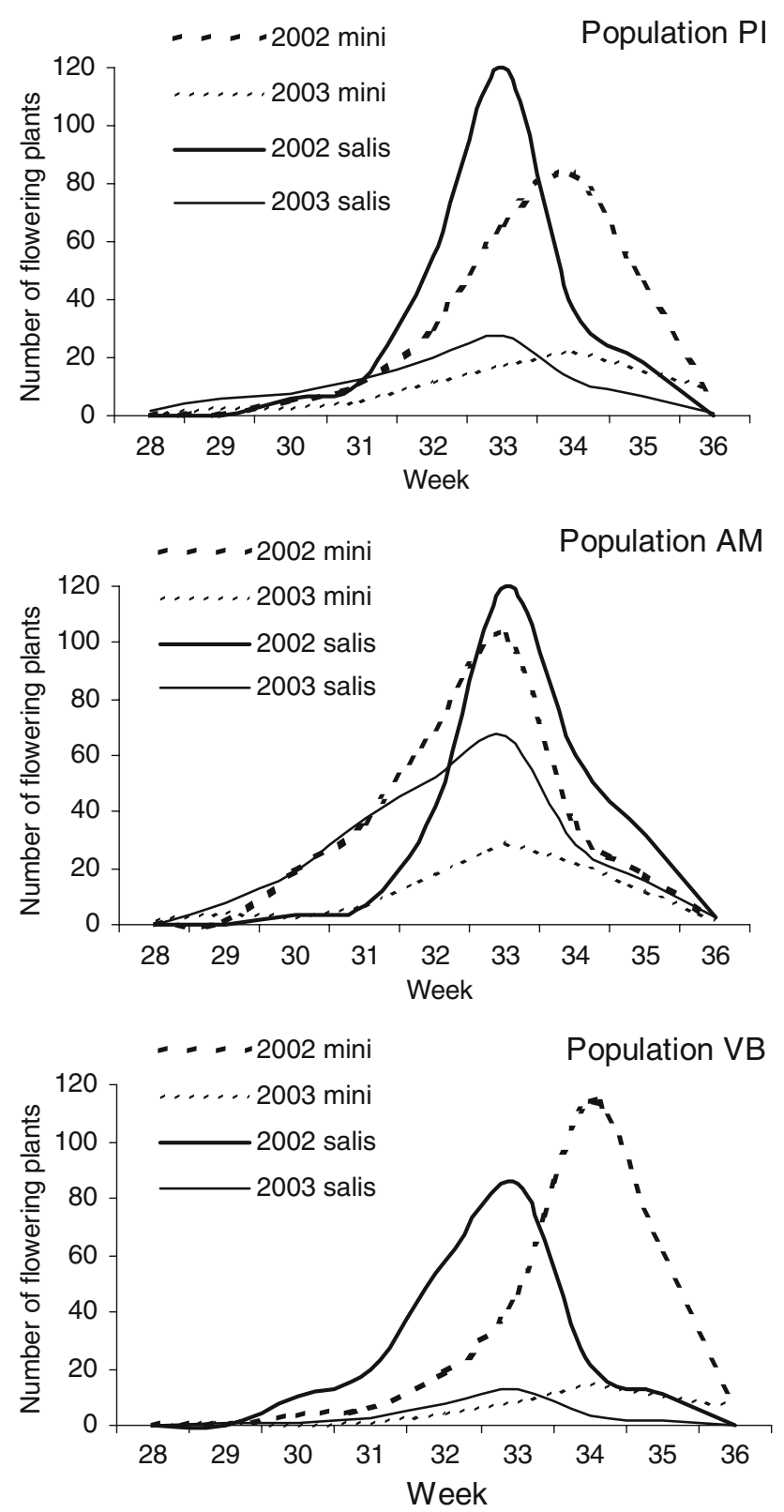

Fig. 2 Mean number of flowering plants of $E$. minima and $E$. salisburgensis in the plots of the artificial populations from Piora (PI), Andermatt (AM) and Valle Bedretto (VB) in 2002 and 2003

Euphrasia plants (28 h), 15 flower visitors were detected. The Euphrasia plants were visited by Hymenoptera and Diptera, ants, small beetles (Nitidulidae and Curculionidae) and one single butterfly. Hymenoptera and Diptera (about 5-10 mm long) were the most frequent flower visitors and often visited more than one Euphrasia plant. Multiple visits of E. salisburgensis (2-9 plants, mean 3.5) occurred 10 times but only once for E. minima (nine plants). Twelve Hymenoptera and Diptera visited at least two different Euphrasia species during a census (behavior 4). Before or after visiting E. salisburgensis, Hymenoptera and Diptera often visited the large-flowered E. alpina.

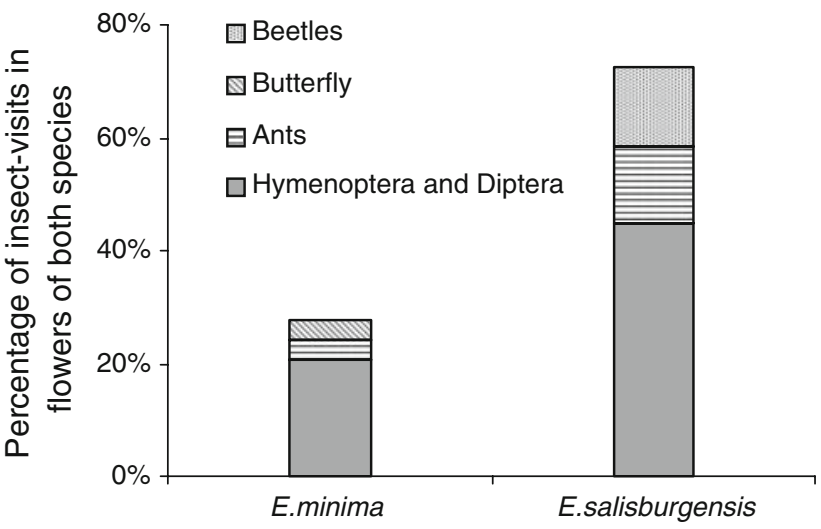

Fig. 3 Percentage of insects visiting one single Euphrasia flower (behavior 1)

The flower-visiting beetles were very small (about $2 \mathrm{~mm}$ ) and were detected by chance when they crawled out or into a flower. In most cases they stayed in a flower during the whole census, probably feeding pollen. The ants behaved similar to the beetles. Ants and beetles either visited only one flower (behavior 1, Fig. 3) or 2-3 flowers of the same inflorescence (behavior 2). Overall, E. salisburgensis was more frequently visited by insects than E. minima, but the proportion of Hymenoptera and Diptera to ants and beetles was similar in both species (Fig. 3; Table 2).

Morphological analyses

Based on morphological characters, 109 E. minima, 80 E. salisburgensis and 25 putative hybrids were determined in 2003 and 2004. In 10 of the 14 characters KruskallWallis tests revealed significant differences between species and/or between species and hybrids (Table 3). Pairwise comparisons found no significant differences in the corolla length of E. minima and E. salisburgensis. Furthermore, E. minima and the hybrids were similar in three characters and E. salisburgensis and the hybrids in one character (Table 3). The values of quantitative

Table 2 Observed and expected number of visitors in flowers of E. minima and E. salisburgensis (behavior 1)

\begin{tabular}{lllllc}
\hline & \multicolumn{2}{c}{ E. minima } & & \multicolumn{2}{c}{ E. salisburgensis } \\
\cline { 2 - 3 } & Observed & Expected & & Observed & Expected \\
\hline $\begin{array}{l}\text { Hymenoptera and } \\
\text { Diptera }\end{array}$ & 5 & 4.5 & 13 & 13.5 \\
$\begin{array}{l}\text { Beetles, ants, butterfly } \\
\text { Chi-square } 0.21, d f \text { 1, not sig. }\end{array}$ & 2 & 2.5 & 8 & 7.5 \\
\hline
\end{tabular}

Test-value from chi-square test 
Table 3 Mean and standard error for quantitative morphological characters of E. minima, E. salisburgensis and their hybrids

\begin{tabular}{|c|c|c|c|c|c|c|c|c|}
\hline \multirow[t]{2}{*}{ Character } & \multicolumn{2}{|c|}{ E. minima $n=109$} & \multicolumn{2}{|c|}{ E. salisburgensis $n=80$} & \multicolumn{2}{|c|}{ Hybrids $n=25$} & \multirow[t]{2}{*}{$P$} & \multirow[t]{2}{*}{ Not sign. } \\
\hline & Mean & Std. error & Mean & Std. error & Mean & Std. error & & \\
\hline Number of lateral shoots & 0.08 & 0.03 & 0.16 & 0.04 & 0.08 & 0.05 & $*$ & $\mathrm{~s} / \mathrm{h}, \mathrm{m} / \mathrm{h}$ \\
\hline Node of the first flower & 6.22 & 0.19 & 6.69 & 0.23 & 6.04 & 0.40 & - & - \\
\hline Total leaf length, mm (a) & 4.51 & 0.07 & 6.62 & 0.15 & 5.34 & 0.27 & $* *$ & \\
\hline Largest width between two teeth, mm (b) & 2.58 & 0.06 & 2.55 & 0.08 & 2.62 & 0.15 & - & - \\
\hline Lateral length of the top tooth, $\mathrm{mm}(\mathrm{c})$ & 1.37 & 0.03 & 2.00 & 0.04 & 1.57 & 0.09 & $* *$ & \\
\hline Width of the upper lateral tooth, mm (d) & 1.22 & 0.02 & 1.80 & 0.04 & 1.43 & 0.09 & $* *$ & \\
\hline Angle of the top tooth (e) & 53.36 & 0.86 & 36.95 & 0.81 & 49.64 & 2.08 & $* *$ & \\
\hline Number of leaf teeth pairs & 2.95 & 0.05 & 2.78 & 0.06 & 2.88 & 0.10 & - & - \\
\hline Ratio total length (a) / width (b) & 1.80 & 0.03 & 2.69 & 0.06 & 2.08 & 0.08 & $* *$ & \\
\hline Ratio total length (a) / length tooth (c) & 3.36 & 0.05 & 3.32 & 0.05 & 3.46 & 0.09 & - & - \\
\hline Length of the upperlip, mm (f) & 5.10 & 0.05 & 5.07 & 0.09 & 5.76 & 0.22 & $*$ & $\mathrm{~s} / \mathrm{m}$ \\
\hline Length of the calyx tooth, $\mathrm{mm}(\mathrm{g})$ & 2.72 & 0.05 & 3.73 & 0.08 & 3.20 & 0.16 & ** & \\
\hline Length of the calyx tooth, mm (h) & 2.02 & 0.05 & 2.64 & 0.06 & 2.22 & 0.12 & $* *$ & $\mathrm{~m} / \mathrm{h}$ \\
\hline Width of the calyx, mm (i) & 2.06 & 0.03 & 2.18 & 0.03 & 2.05 & 0.07 & $*$ & $\mathrm{~m} / \mathrm{h}$ \\
\hline
\end{tabular}

Letters in parentheses refer to measurements explained in Fig. 1

Column $P$ : levels of significance from Kruskal-Wallis tests for differences between the three groups $\left(* P<0.05 ; * * P<10^{-12}\right.$ )

Column "not sign.": taxa that are not significantly different at the 0.05 level

$m$ E. minima, $s$ E. salisburgensis, $h$ hybrid

characters of the putative hybrids in nearly all cases overlapped with values of one or both parental species. Mean character values of the hybrids were either intermediate or larger or smaller than those of the parental species. The upper lip of the corolla in all populations was significantly larger in the hybrids than in the putative parental species (Table 3).

With the exception of two white flowering plants, all E. minima plants had yellow corollas. E. salisburgensis plants from the artificial populations PI and AM flowered white, while three of the four E. salisburgensis in the artificial population VB had violet flowers. Most hybrids had white flowers (Fig. 4), but in two populations plants occurred whose flowers changed color from yellow to white during anthesis. This phenomenon was also observed in artificially produced hybrids of E. minima and E. salisburgensis and in (tetraploid) hybrids of $E$. christii and E. hirtella in previous garden experiments (Liebst and Schneller 2005; Liebst 2006). In plants from the populations PI and AM, cilia were mostly present on the surface of the capsules in E. minima and absent in the capsules of E. salisburgensis. In E. minima plants from the artificial population VB, capsule cilia and hairs on the leaves were present or absent in a similar number of plants. Hybrids either had glabrous or ciliate capsules and glabrous or hairy leaves (Fig. 4). E. minima and E. salisburgensis differed significantly in qualitative morphological characters (Table 4).

\section{Discriminant analyses}

Both qualitative and quantitative characters were used in the discriminant analysis (Table 5). Capsule and leaf indumentum characters were most powerful in discriminating species and hybrids (test of equality of group means, the two characters with the smallest Wilks's lambda values). The discriminant analysis resulted in statistically significant separation of species and hybrids in univariate and multivariate $F$ tests $(P<0.01)$, with the first canonical function accounting for most of the spread (Fig. 5). A priori classification of E. minima, E. salisburgensis and hybrids was correct in 97.2, 94.7 and 64\%, respectively.

\section{RAPD analyses}

In total 44 E. minima, 41 E. salisburgensis and seven plants determined as hybrids were used for RAPD analysis. A total of 40 repeatable polymorphic banding fragments were detected (540-3,000 base pairs, six primers), 24 of them occurring either with more than $80 \%$ in both species or with less than $80 \%$ in one or both of the species. The remaining 16 banding fragments occurred with $\geq 80 \%$ in one of the species, but with up to $25 \%$ in the second species too (Table 6). These bands were called "specific" for a species. UPGMA clustering did not separate the species and hybrids, when data of the populations were pooled and when all banding fragments were used in the analysis. 
Fig. 4 Frequencies of qualitative morphological characters
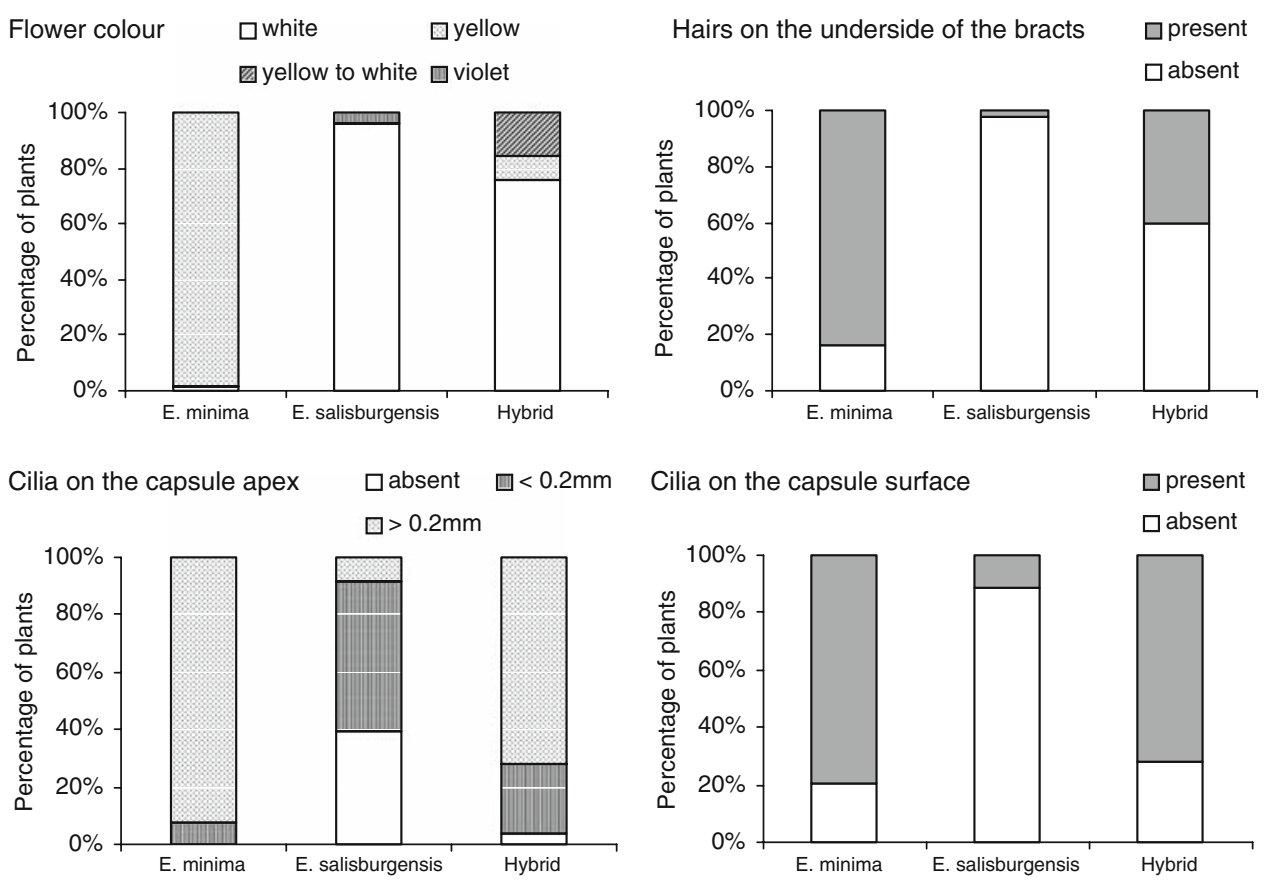

Table 4 Observed and expected frequencies of qualitative characters and test-values from chi-square tests

\begin{tabular}{|c|c|c|c|c|c|c|}
\hline & \multicolumn{2}{|l|}{ E. minima } & \multicolumn{2}{|c|}{ E. salisburgensis } & \multicolumn{2}{|l|}{ Hybrids } \\
\hline & Observed & Expected & Observed & Expected & Observed & Expected \\
\hline \multicolumn{7}{|c|}{ Hairs on the underside of the bracts } \\
\hline Absent & 18 & 56.8 & 79 & 42.2 & 15 & 13.0 \\
\hline Present & 91 & 52.2 & 2 & 38.8 & 10 & 12.0 \\
\hline \multicolumn{7}{|c|}{ Chi-square $122.9, d f 2, P<0.001$} \\
\hline \multicolumn{7}{|l|}{ Cilia on the capsule apex } \\
\hline No cilia or cilia $<0.2 \mathrm{~mm}$ & 8 & 45.1 & 74 & 33.5 & 7 & 10.3 \\
\hline Cilia $>0.2 \mathrm{~mm}$ & 101 & 63.9 & 7 & 47.5 & 18 & 14.7 \\
\hline \multicolumn{7}{|c|}{ Chi-square 137.3, $d f 2, P<0.001$} \\
\hline \multicolumn{7}{|l|}{ Cilia on the capsule surface } \\
\hline Absent & 22 & 51.2 & 72 & 38.1 & 7 & 11.7 \\
\hline Present & 87 & 57.8 & 9 & 42.9 & 18 & 13.3 \\
\hline Chi-square 92.2, $d f 2, P<$ & & & & & & \\
\hline
\end{tabular}

When populations were analyzed separately and when only "specific" bands were used in the analysis, E. minima and E. salisburgensis were separated into two main clusters with the exception of seven plants (Fig. 6).

In most of the plants determined as hybrids a combination of bands predominantly occurring either in $E$. minima or in E. salisburgensis was found. Within the cluster E. minima of population PI, a cluster consisting of hybrids and one plant of E. salisburgensis (s1) and of E. minima (m2) was built. Each of the latter showed a combination of band patterns of both species, thus revealing their hybrid origin (Fig. 6). Within the cluster E. minima of population AM, a cluster consisting of one hybrid and two plants of E. minima (m8, m11) and one $E$. salisburgensis plant (s10) was built. Banding patterns of the latter also revealed their hybrid origin (Fig. 6; Table 7).

Within the clusters of E. salisburgensis and E. minima in PI and AM, few plants of different species or hybrids were found. Banding patterns in most of these cases indicated that the plants were misidentified using morphological characters (Fig. 6; Table 7). 
Table 5 Standardized canonical discriminant function coefficients

\begin{tabular}{|c|c|c|}
\hline & \multicolumn{2}{|l|}{ Factor } \\
\hline & 1 & 2 \\
\hline Flower color $^{\mathrm{a}}$ & 0.252 & 0.597 \\
\hline Calyx tooth length $(a)^{b}$ & -0.205 & -0.129 \\
\hline Calyx tooth length $(b)^{\mathrm{a}}$ & 0.074 & 0.165 \\
\hline Calyx width $(\mathrm{c})^{\mathrm{b}}$ & -0.014 & 0.242 \\
\hline Capsule cilia surface & 0.035 & -0.407 \\
\hline Capsule cilia apex ${ }^{\mathrm{a}}$ & 0.431 & -0.507 \\
\hline Total leaf length $(a)^{b}$ & -0.096 & -0.747 \\
\hline Top tooth length $(\mathrm{c})^{\mathrm{b}}$ & -0.288 & 0.767 \\
\hline Lateral tooth width $(\mathrm{d})^{\mathrm{b}}$ & -0.195 & -0.005 \\
\hline Angle top tooth $(\mathrm{e})^{\mathrm{b}}$ & 0.423 & -0.155 \\
\hline Hairs on the underside of the bracts ${ }^{\mathrm{a}}$ & 0.424 & 0.501 \\
\hline Ratio leaf length (a)/width (b) ${ }^{\mathrm{b}}$ & -0.206 & 0.046 \\
\hline Ratio leaf length (a)/length tooth (c) ${ }^{\mathrm{b}}$ & -0.329 & 0.379 \\
\hline Number lateral shoots ${ }^{b}$ & 0.011 & 0.074 \\
\hline Variation explained (\%) & 97.1 & 2.9 \\
\hline Canonical correlation & 0.920 & 0.379 \\
\hline
\end{tabular}

Letters in parentheses refer to measurements explained in Fig. 1

Character transformation: ${ }^{\mathrm{a}}$ Vector transformation, ${ }^{\mathrm{b}}$ Element and vector transformation (Gower)

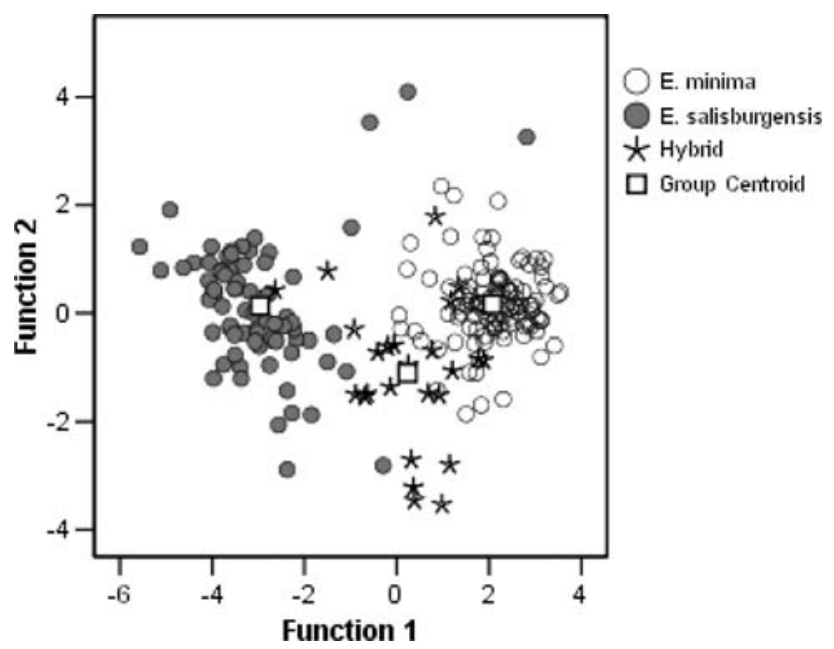

Fig. 5 Placement of plants of E. minima, E. salisburgensis and hybrids along the first and second discriminant function

\section{Discussion}

Preconditions for the production of hybrids

Overlapping flowering seasons in the artificial populations of Euphrasia enabled intra- and inter-specific cross-pollination of E. minima, E. salisburgensis and the indigenous large-flowered E. alpina, but neither the small- nor the large-flowered species attracted many insects. However, compared with studies of Gomez (2002) and Kreisch
Table 6 Polymorphic amplification products occurring in at least $80 \%$ of the individuals of one of the species and in not more than $25 \%$ of the individuals of the second species

\begin{tabular}{lll}
\hline Primer code & $\begin{array}{l}\text { Primer sequence } \\
\left(5^{\prime} \text { to } 3^{\prime}\right)\end{array}$ & $\begin{array}{l}\text { No. of polymorphic } \\
\text { bands considered }\end{array}$ \\
\hline OPA-19 & CAAACGTCGG & 1 \\
OPC-13 & AAGCCTCGTC & 4 \\
OPD-03 & GTCGCCGTCA & 4 \\
OPD-19 & CTGGGGACTT & 5 \\
OPD-20 & ACCCGGTCAC & 2 \\
\hline
\end{tabular}

Primer code, primer sequence and the number of bands considered

(1996) (four or no visitors in small-flowered alpine $E u$ phrasia species), the number of insect visits observed in the present study was much higher. The differences in the observed number of insects visiting Euphrasia flowers may be due to differences in the habitat, for instance the altitudinal zone $(2,550-2,600 \mathrm{~m}$ in the studies of Kreisch (1996) and Gomez (2002), 1,960 $\mathrm{m}$ in the present study) or in the observation methods.

The very small beetles and ants observed in some of the Euphrasia flowers probably did not pollinate the flowers or pollinated flowers with pollen of the same inflorescence (geitonogamy). Conversely, the size and the behavior of most of the Hymenoptera and Diptera means that pollen could have been caught when creeping into a flower and deposited on the stigma of a second one.

Both E. minima and E. salisburgensis (and E. hirtella and E. alpina) were visited by Hymenoptera and Diptera, but $E$. salisburgensis was more frequently visited than $E$. minima, probably caused by a difference in the amount of nectar or pollen produced by each species. Both species possess small nectary discs at the bases of their ovaries (pers. obs.), but nectar could not be detected either in flowers of E. minima or in E. salisburgensis flowers. Largeflowered Euphrasia species are expected to produce more nectar than small-flowered species (Knuth 1909), but only one insect was observed successively visiting a large number of $E$. alpina flowers. There was no uniform pattern when insects visiting $E$. salisburgensis changed to the next plant. However, except in one case, insects visiting $E$. minima did not visit a second one, even if E. minima was as abundant as E. salisburgensis in the plot. These results indicate that insects probably discriminated between $E$. minima and E. salisburgensis by their flower colors.

Detection of hybrids

RAPD analyses

RAPD banding patterns confirmed the occurrence of hybrids between E. minima and E. salisburgensis in two of 
Fig. 6 UPGMA clustering in the populations Piora and Andermatt. In population Valle Bedretto (not shown), no hybrids were detected and $E$. minima and E. salisburgensis were clustered in two groups similar to populations PI and AM. $m$ E. minima,

$s$ E. salisburgensis, $h$ hybrid
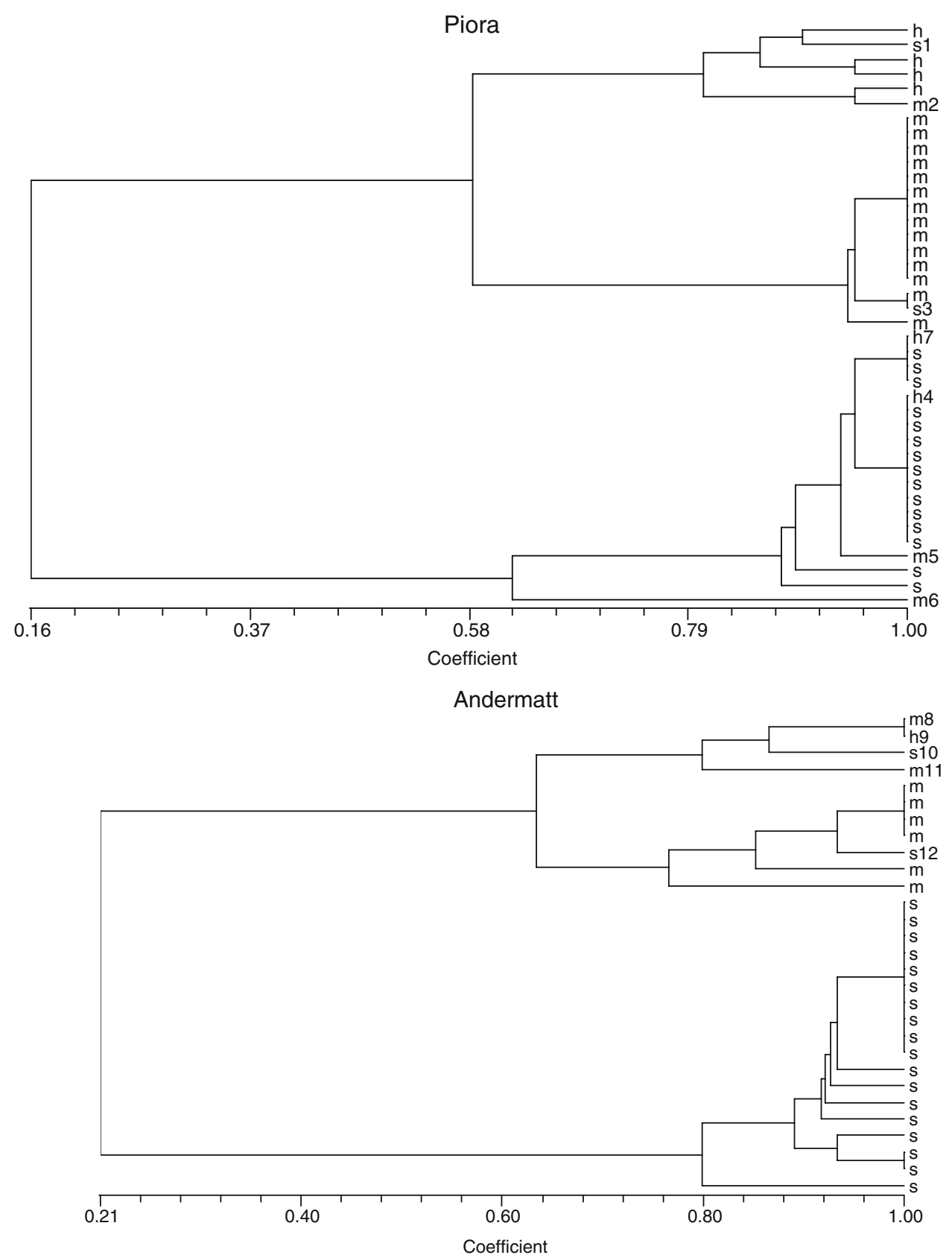

Table 7 RAPD bands of plants of the populations PI and AM

\begin{tabular}{|c|c|c|c|c|c|c|c|c|c|c|c|c|}
\hline \multirow[t]{2}{*}{ Plant } & \multicolumn{7}{|c|}{ Piora } & \multicolumn{5}{|c|}{ Andermatt } \\
\hline & $\mathrm{m} 2$ & $\mathrm{~m} 5$ & $\mathrm{~m} 6$ & s1 & s3 & h4 & h7 & $\mathrm{m} 8$ & h9 & s10 & $\mathrm{m} 11$ & s12 \\
\hline No. of bands specific for $E$. minima & 7 & 0 & 6 & 7 & 8 & 0 & 1 & 12 & 8 & 8 & 8 & 8 \\
\hline No. of bands specific for E. salisburgensis & 4 & 5 & 4 & 5 & 0 & 6 & 5 & 6 & 5 & 6 & 5 & 0 \\
\hline
\end{tabular}

Plant names refer to Fig. 6

the artificially established populations and detected plants of hybrid origin that had been identified either as E. minima or E. salisburgensis. In contrast to a previous study of Liebst (2006) in which specific RAPD bands occurred in each of the species, in the present study no such patterns have been found. The predominance of bands in one of the species and the occurrence of these bands in some plants of the second species point to introgression between $E$. $m i n$ ima and E. salisburgensis in the origin populations. Yeo (1978) argued that introgression occurs mainly when there 
are strong barriers to interbreeding, for instance between diploids and tetraploids, and that it also takes place across the high sterility barrier between subsection Angustifoliae and Ciliatae. In these cases the F1 generation is expected to produce no or few offspring, but back-crossing the hybrids would more likely result in fertile offspring. Evidence for gene exchange between species is also given by a morphological characteristic. Some E. salisburgensis plants had ciliate instead of glabrous capsules, a characteristic important in the separation of subsections Ciliatae and Angustifoliae. The occurrence of these plants suggests introgression of genes from E. minima.

\section{Morphological and discriminant analyses}

The hybrids detected in the artificial populations may have resulted from interspecific cross-pollination (F1 hybrids) or from selfing or back-crossing of the hybrids (F2 hybrids); both types could have descended from the seedings. However, the RAPD banding patterns indicate that they may also be descendants from hybrids backcrossed with one of the species in their origin populations. Furthermore, they could be offspring from hybrids or from backcrossed hybrids present in the surroundings of the artificial populations. In contrast to $\mathrm{F} 1$ and $\mathrm{F} 2$ hybrids which express a combination of morphological characteristics of both species, offspring from hybrids backcrossed with one of the parental species often show the habitus of the species with which they were backcrossed and only few characteristic from the other (Liebst 2006). In the present study, the number of hybrids classified correctly was in accordance with the classification of F1 and F2 hybrids in the study mentioned above (Liebst 2006). Because the history of the plants identified as hybrids in the present study is unknown, no further interpretation of the classification in the discriminant analysis is possible. However it is assumed that due to the high sterility of F1 hybrids, few or no F2 hybrids occurred in the artificial populations.

Some of the plants identified as hybrids in the artificial populations differed from hybrids of E. minima and E. salisburgensis produced experimentally in a greenhouse experiment (Liebst 2006). In contrast to the latter that mostly had yellow flowers at least in the beginning of the anthesis and had hairs on the underside of the leaves, many of the hybrids in the artificial populations had white flowers and often had glabrous leaves. Both characters point to parental species with white flowers and glabrous leaves. Besides E. salisburgensis (4n) that has these characteristics, the white flowering, glabrous leaved E. alpina (2n) occurred in some of the plots and could be one hybrid parent. Insect-visits of both species indicate that interspecific cross-pollination is likely to occur. The different ploidy levels however should suggest that viable hybrids are rare. Liebst and Schneller (2005) did not obtain offspring when crossing E. minima (4n) and E. rostkoviana (2n). In contrast, Pugsley (1930) and Yeo (1956) hypothesized that tetraploid and diploid Euphrasia species could produce triploid offspring, so hybridization between E. alpina and E. salisburgensis could not be excluded.

During the flowering period of Euphrasia only few insect-pollinated plant species flowered within and around the plots and consequently insects were seldom in the whole area. So, independent of the flower size of $E u$ phrasia, the chance of cross-pollination was reduced. Yeo (1968, 1978a) argued that cross pollination of small-flowered Euphrasia species may be supported by an attractive plant species growing in the surrounding of Euphrasia, for instance by Calluna vulgaris, associated with E. micrantha. Yeo suggested that E. micrantha may depend on a sufficient frequency of mistaken visits by insects visiting the flowers of Calluna, to provide it with a moderate degree of outcrossing. Occasionally when surrounded by species with flowers different in color and size, mistaken visits of $E u$ phrasia flowers may also occur thus increasing inter- and intraspecific crossing.

Between five and six putative hybrids were found in each of the artificial populations in 2003. Assuming that all of these plants had grown from seeds resulting from interspecific crossing in 2002 and assuming a germination and survival rate of $3.5 \%$, an estimated 160 seeds were produced by interspecific pollination in each of the artificial populations in 2002. Further considering a mean seed set of 6.3 (result of artificial interspecific pollination of $E$. minima and E. salisburgensis, data not published), this corresponds to about 25 flowers that had to have been pollinated by insects. Taking into consideration that most flowers of E. minima and E. salisburgensis are selfing in an early stage of the anthesis, it may be expected that few seeds in a fruit resulted from cross-pollination. Thus, the number of flowers that had to be visited by an insect is probably much higher. This estimation demonstrates that even in small populations of Euphrasia with low abundance of insects a moderate number of flowers are probably cross-pollinated, thus both conserving the genetic variability within a population and allowing hybridization between species.

\section{Conclusions}

The small number of flowers and the small flower sizes did not prevent cross-pollination in the artificial populations of E. minima and E. salisburgensis. Considering that Euphrasia often naturally occurs in large populations and that vigorous plants may bear up to 25 open flowers at the same time (Liebst 1999), crossing probably is much more 
frequent than observed in the present study and more common than has been expected so far.

\section{They do hybridize in their natural habitat}

Hybrids were detected in both years following the establishment of the artificial populations. Nearly all hybrids which were investigated by RAPD analyses revealed their descent from E. minima and E. salisburgensis by their banding patterns. RAPD banding patterns also revealed the hybrid origin of some plants that had been determined as E. salisburgensis or E. minima, respectively. The predominance of a band fragment in one of the species and the occurrence of this band in some plants of the second species point to introgression of genes from E. minima to E. salisburgensis and vice versa in their origin populations.

Acknowledgments I thank Jakob Schneller for advice throughout the planning and completion of this project and an unknown reviewer for helpful comments on the manuscript. In addition, I thank Chloe Galley for help with the English text. This work was supported in part by the Claraz Stiftung.

\section{References}

Brochmann C (1987) Evaluation of some methods for hybrid analysis, exemplified by hybridization in Argyranthemum (Asteraceae). Nord J Bot 7:609-630

De Greef B, Triest L (1999) The use of random amplified polymorphic DNA (RAPD) for hybrid detection in Scirpus from the river Schelde (Belgium). Heredity 8:379-386

French GC, Ennos RA, Silverside AJ, Hollingsworth PM (2005) The relationship between flower size, inbreeding coefficient and inferred selfing rate in British Euphrasia species. Heredity 94:44-51

Gomez JM (2002) Self-pollination in Euphrasia willkommii Freyn (Scrophulariaceae), an endemic species from the alpine of the Sierra Nevada (Spain). Pl Syst Evol 232:63-71

Gower JC (1971) A general coefficient of similarity and some of its properties. Biometrics 271:857-871

Heinricher E (1924) Methoden der Aufzucht und Kultur der parasitischen Samenpflanzen. In: Abderhalden E (ed) Handbuch der biologischen Arbeitsmethoden. E. Abderhalden, Berlin, pp 237-350
Hess HE, Landolt E, Hirzel R (1972) Flora der Schweiz. edn.3. Birkhäuser, Basel, pp. 240-247

Knuth P (1909) Handbook of flower pollination 3

Kreisch W (1996) Vergleich der Polstervegetation in Hochgebirgen Mittel- und Nordeuropas aus blütenökologischer Sicht. Dissertationes botanicae 271. J. Cramer, Berlin Stuttgart

Lachenbruck PA (1975) Discriminant analysis. Wiley Interscience, New York

Liebst B (1999) Euphrasia minima. Aspekte des Lebenszyklus und phänotypische und genotypische Variabiliät. Diplomo thesis, University of Zurich

Liebst B (2006) An experimental study of germination and intra- and interspecific pollination in alpine taxa of Euphrasia. Dissertation, University of Zurich

Liebst B, Schneller J (2005) How selfing and intra- and interspecific crossing influence seed set, morphology and ploidy level in Euphrasia: an experimental study of species occurring in the Alps of Switzerland. Pl Syst Evol 255:193-214

Matthies D (1998) Influence of the host on growth and biomass allocation in the two facultative root hemiparasites Odontites vulgaris and Euphrasia minima. Flora 193:187-193

Pugsley HW (1930) A revision of the British Euphrasiae. Bot J Linn Soc 48:467-544

Rohlf JF (2004) tpsDig (2.02)

Sokal RR, Rohlf JF (1981) Biometry. W.H. Freeman and Co., New York

Vitek E (1986) Evolution alpiner Populationen von Euphrasia (Scrophulariaceae): die tetraploide E. minima. Pl Syst Evol 151:241-269

von Wettstein R (1893) Untersuchungen über Pflanzen der österreichisch-ungarischen Monarchie: die Arten der Gattung Euphrasia. Oesterr. Bot. Z. 18

von Wettstein R (1896) Monographie der Gattung Euphrasia. Wilhelm Engelmann, Leipzig

Yeo PF (1956) Hybridization between diploid and tetraploid species of Euphrasia. Watsonia 3:253-269

Yeo PF (1964) The growth of Euphrasia in cultivation. Watsonia 6:124

Yeo PF (1966) The breeding relationship of some European Euphrasiae. Watsonia 6:216-245

Yeo PF (1968) The evolutionary significance of the speciation of Euphrasia in Europe. Evolution 22:736-747

Yeo PF (1976) Artificial hybrids between some European diploid species of Euphrasia. Watsonia 11:131-135

Yeo PF (1978) A taxonomic revision of Euphrasia in Europe. Bot J Linn Soc 77:223-334

Yeo PF (1978a) Euphrasia: a taxonomic critical group with normal sexual reproduction. In: Street HE (ed) Essays in plant taxonomy. Academic Press, London 